\title{
RESEARCH OF ECO-GEOGRAPHICAL SITUATION OF LANKARAN PHYSICAL-GEOGRAPHICAL REGION AND GROUPING OF ECOLOGICALLY TENSE ZONES
}

\author{
Zaur Imrani Tahir ${ }^{1}$, Shakar Mammadova Idayat ${ }^{2}$, Ulker Babayeva Allahyar ${ }^{3}$ \\ ${ }^{1}$ The Institute of Geography after academician H.Aliyev, Azerbaijan National Academy of \\ Sciences. Baku, Azerbaijan. \\ ${ }^{2}$ Baku State University. Baku, Azerbaijan. \\ ${ }^{3}$ Lankaran State University/ Lankaran, Azerbaijan.
}

Email: zaur_imrani@mail.ru (Zaur Imrani Tahir), sheker.mammadova@mail.ru (Shakar Mammadova Idayat), babayevauka@gmail.com (Ulker Babayeva Allahyar )

ORCID: https://orcid.org/0000-0002-0606-3753 (Zaur Imrani Tahir)

https://orcid.org/0000-0002-4420-4414 (Shakar Mammadova Idayat)

https://orcid.org/0000-0001-5174-5107 (Ulker Babayeva Allahyar )

\begin{abstract}
The intensive use of natural resources in modern times has led to several eco-geographical problems, the solution of which is possible through the interaction of science and technology. Because the constant growth of the population leads to an increase in socio-economic needs. At the same time, the use of nature becomes more intensive, and as a result, the amount of damage to the environment increases and its area expands. From this point of view, it is very
\end{abstract}


important to study any research area in an eco-geographical direction on a scientific and methodological basis.

In the Lankaran physical-geographical region we studied, the elements of the natural environment have undergone biological, physical and chemical changes as a result of human life and economic activity, and there is a need for nature protection. These include environmental facilities, ie settlements, industrial zones, agricultural areas, roads, recreation facilities, etc. belongs to. These factors cause eco-geographical problems in certain areas and require solutions. From this point of view, the article examines the current eco-geographical situation of Lankaran physical-geographical region and groups the ecologically tense zones of the region. Eco-geographical stress zones are grouped into three categories - areas with low, moderate and high levels of environmental damage, and each zone includes settlements and their surrounding areas.

As a result of the study of the eco-geographical situation and the grouping of ecologically tense zones, the "Eco-geographical map of Lankaran physical-geographical region" was compiled. The map shows the development of the light industry, food industry, fisheries, agriculture and tourism, which are some of the main objectives.

Keywords: ecogeography, ecological stress zones, ecological damage, grouping, environment, pollution.

\section{INTRODUCTION}

The proper and efficient use of nature in our time is one of the most important problems facing mankind. The rapid growth of the world's population has led to an intensification of the use of natural resources. Although scientific and technological progress has reduced people's dependence on nature, the eco-geographical problems posed by the use of nature have become complex and dangerous. All this has linked the efficient use of natural resources and the organization of nature protection work with sustainable socio-economic and environmental development. From this point of view, the study of the eco-geographical condition of the air, soil and water, as well as the natural conditions of flora and fauna, the problems caused by the use of nature and their solutions attracts attention. 
To date, no academic consensus has been reached on the evaluation of the sustainability of processes and/or resources, given their extraordinary scientific complexity. Development policies must jointly consider socio-economic and environmental effects so that both the contributions of the environment and the contributions of the economy to human well-being are valued fairly (Amarante, Schulz, Romero, Bastida \& Güereca, 2021).

The independence of the Republic of Azerbaijan, production relations characterized by a market economy and based on the efficient use of nature have had a negative impact on the eco-geographical situation of the surrounding areas. In the regions of our republic, this factor has become more pronounced. One of such regions is Lankaran physical-geographical region.

\section{THE OBJECT OF RESEARCH}

The territory of Lankaran physical-geographical region is 6.08 thousand $\mathrm{km} 2$ and makes up $7 \%$ of the republic's territory. 6 districts (Astara, Lankaran, Lerik, Masalli, Jalilabad and Yardimli), 8 cities (Astara, Lankaran, Liman, Lerik, Masalli, Jalilabad, Goytapa, Yardimli), 13 settlements (Kijaba, Archivan, Narimanabad, Garmatuk, Hirkan, Ashagi Nuvedi, Haftoni, Istisu, Balygchilar, Shirinsu, Boradigah, Arkivan, Novagolovka), 642 rural settlements. A total of 937.2 thousand people (2019) live in these settlements, which also have a density of 154 people per $\mathrm{km}^{2}$ (Regions of Azerbaijan, 2019). Although the level of urbanization in the province is low, the population density is higher in cities and towns, as well as in their surrounding areas. The main agricultural enterprises and agricultural fields of the region are located in these areas.

\section{MATERIALS AND RESEARCH METHODS}

Theoretical bases of the research were studied by foreign scientists V.I.Vernadsky, A.A.Grossheim, A.Y.Gaev, A.I. Zarubov, Q.H. Golubev, V.I. Sturman, K.M.Petrov, M. Parra-Quijano, E. Torres and others, and in Azerbaijan and Lankaran physical-geographical region H.A. Aliyev, Sh.Y.Goychayli, M.Y.Khalilov, G.Sh.Mammadov, A.A.Gurbanzade, S.Z.Mammadova, N.A.Sadigova, T.B.Huseynov, E.Atashova, Sh.I.Mammadova and others organize scientific works, methodical instructions, as well as scientific-research works carried out by the author. Historical-geographical approach, comparison, systematic analysis, 
Geographic Information Systems (GIS), field observations, etc. methods were used in carrying out the research work.

\section{ANALYSIS AND DISCUSSION}

In modern times, the urban environment is very different from the environment of natural ecosystems. It is also characterized by contamination with chemicals and microorganisms, increasing levels of physical exposure (noise, vibration, electromagnetic fields). At a time when the risk of road accidents and industrial accidents is increasing, all environmental problems in settlements are related to human activities. The most acute problems of the environment are air pollution, the problem of "clean water", the protection of vegetation and soil, waste management (Khomich, 2002).

In the last 30 years, the area of settlements in Lankaran physical-geographical region has been expanded, new settlements have been built. This was mainly manifested in the surrounding areas of district centres and along roads. In terms of population density, these areas are denser than other settlements in the region. This process is mainly reflected in the settlement and urban development of the population and requires the application of a geographical approach. However, practical work in this area, especially constructive approaches, has hardly been taken into account in determining the strategic directions and future environmental situation in the socio-political life and management of the country.

As in other regions of the republic during the Soviet period, the settlement of the rural population in Lankaran physical-geographical region is usually developed based on agroindustrial complexes and agro-industrial associations. During the years of independence, rural forms of the settlement were formed in the conditions of market relations. The activity of industries in densely populated areas disturbed the balance of the natural environment on the ground, and settlements were assessed not based on their functional development, but based on the settlement zone. This process is managed regardless of the level of development and social-production structure of the region. However, currently, there is a small number of industrial enterprises and their capacity in the province, insufficient employment of the population, as well as changes in the settlement system. Thus, the problem of unemployment is becoming more pronounced due to population growth. From this point of view, even in large and densely populated settlements, the main occupation of the population is related to agriculture. 
Industrial ecology, which is related to the eco-geographical problems of the region, takes into account not only the impact of human activities on the natural environment but also the impact of polluted environments on human health. Because of any technological process is associated not only with production but also with production waste. Harmful organic substances from industrial wastes are oxidized with the active participation of soil flora and fauna. Contamination of water bodies with industrial wastewater changes the $\mathrm{pH}$ of the water, which leads to the death of aquatic organisms or the replacement of some species with others.

Industrial emissions into the atmosphere include sulfur, nitrogen, ash, dust, silicates, hydrocarbons, hydrogen fluoride, ozone and others. compounds, many of which harm living organisms. Thus, silicon dioxide ( $\mathrm{SiO} 2)$ particles have a negative effect on fibrosis, sulfur oxides (SO2 and SO3) on the respiratory tract, nitrogen oxides (NO and $\mathrm{NO} 2$ ) on lung tissue, ozone (O3) on lung tissue, respiratory tract, red blood cells, carbon monoxide (CO) causes a decrease in oxygen (Deryabin, 2016).

The distribution of crop production and diversity is often as dependent on people as on biogeographic considerations. Indeed, a case can be made for using the term 'agrogeographic' for crop ecogeographic studies, to highlight the importance of the human dimension (Guarino, Maxted \& Chiwona, 2005).

Lankaran physical-geographical region is one of the most important agricultural regions of the republic, where the agro-industrial sector has been developed on the basis of citrus fruits and livestock products. The lowland part of the province has been developed more intensively in terms of agriculture. As a result of high humidity in the area and intensive irrigation of crops, lands in some areas have been degraded, their physical, hydro-physical and other properties have changed, causing soil deterioration. In addition to improper land reclamation measures, the over-fertilization of crops has also damaged the structural composition of soils. Land degradation in the lowlands has also been affected by a large number of settlements and densely populated areas. In the foothills and mountainous areas (mainly on the southern slopes of the mountains), the slope of the relief created conditions for the intensification of the erosion process, affecting the composition and density of vegetation. Yellow mountain-forest, brown mountain-forest, brown mountain-forest soils are widespread in these areas. 
We know that the biological productivity of ecosystems is lower in cultural landscapes, ie in agricultural fields. Another factor is the excessive use of pesticides (toxic chemicals) to increase the productivity of crops and improve product quality, which leads to soil pollution, which in turn has a negative impact on the formation of biological mass. The plains of the region we are studying and the areas close to the Caspian coast face such negative situations. This problem is also closely related to food production. In this case, to meet the demand for food, it is necessary to organize the protection of lands, as well as their efficient and economical use.

Transport plays a mediating role in the establishment of a multifaceted relationship between nature, population and production processes. Because transport does not produce material products, it completes the production process during the delivery of industrial and agricultural products to the place of consumption. Its products - transportation of goods and passengers - are integrated with the process of transport production. Transport also plays an important role in the social, economic and environmental development of the region.

The purpose of the development of transport in modern conditions is to create a system that fully meets its needs and meets the requirements of safety and environmental protection. However, the negative impact of transport on the environment is constantly growing (Kochinov \& Kochinova, 2014). It should not be forgotten that transport systems are linked to a wide range of environmental issues, from the global to the local level. The impact of transport on the environment is primarily related to the type of transport, energy supply and infrastructure. Vehicles that consume large amounts of energy, especially gasoline and diesel, emit large amounts of pollutants, such as carbon dioxide, nitrogen oxides, and noise, damaging many environmental systems (Rodrigue, 2020).

Among the modes of transport, road transport has a more negative impact on the environment and its ecological condition. Harmful substances emitted from vehicles pollute the atmosphere, and oils from internal combustion engines fall to the ground (Alexandrov, Kuzubova \& Yablokova, 1995). However, one of the important factors is to determine the number of pollutants emitted from vehicles. This, in turn, is determined by traffic jams, the number of vehicles moving at the same time and the characteristics of the road network (Korendyaseva, 2017).

In the Lankaran physical-geographical region, where we are conducting research, one of the economic sectors that cause the most damage to the environment is road transport. As a 
result of our research, it was determined that the most affected areas are the surrounding areas of the highways on the North-South International Transport Corridor. The high intensity of traffic, the large number of settlements, the dense population, as well as the location of industrial areas and agricultural bases along the highway has made the area an eco-geographically tense zone.

Forests can be considered as the main recreational resources of Lankaran physicalgeographical region. The forests of the region are very rich and characterized by a variety of vegetation. The fresh air of the forests, aesthetic landscapes, endemic and relict plants attract more tourists. They prefer to relax in the woods and organize picnics.

According to historical data, forests, which once accounted for $60-65 \%$ of the province's territory, have now been reduced to $25-30 \%$. In the lowlands of the region, xerophilous and hirkan-type oak forests have been almost destroyed. This type of forest remains only in mountainous and foothill areas. As a result of human life and economic activities, the ecosystem of the lowland has been changed, settlements and infrastructure facilities have been built in the forest areas, and backyard gardening and planting areas have been laid. Currently, one of the most forested areas in the province is Hirkan National Park. The average annual temperature in the national park varies between $12-14^{0} \mathrm{C}$.

The average temperature is $1-3.7^{\circ} \mathrm{C}$ in January and $22-24.5^{\circ} \mathrm{C}$ in July. The absolute minimum temperature was $-16^{\circ} \mathrm{C}$ and the absolute maximum was $38^{\circ} \mathrm{C}$ (Reserves of the USSR, 1990). The territory of Hirkan National Park is also one of the areas with the least impact and transformation by human economic activity and has a high biological diversity (Yusifov \& Haciyev, 2004). Climatic indicators and rich biodiversity have made the area suitable for tourism. At present, various excursions and picnics have been organized in the national park, which has partially affected the eco-geographical condition of the forests. Because of the tourists who came to the area caused the formation of pollution centres, albeit in small areas. Waste management in the area is carried out by employees of the national park.

\section{ECO-GEOGRAPHICAL STRESS ZONES}

The selection of assessment criteria varies depending on the natural resource management type. Obtained results are compared with parameters that are indicative for or specific to naturally occurring landscape (Golubeva, Ignatieva, Korol \& Toporina, 2012). 
In order to analyze the eco-geographical conditions of Lankaran physical-geographical region, we first of all study the settlements in the region, their population density (50 and fewer people per hectare, 50-100 people, 100-200 people and more), land fund - rural We have mapped farmland, pastures (winter and summer pastures), unused and unusable areas, forests, swamps and rocky areas. Then we mentioned the areas of agriculture - light industry, food industry, agriculture, used for fishing and the development of the tourism sector. All these factors have been summarized and the development trends of the economic sectors have been identified. As a result, the eco-geographical stress zones of the region are marked on the map in 3 categories - areas with low, medium and high ecological damage.

Areas with low ecological damage are Kijaba, Siyakesh, Tengerud, Mashkhan, Mahmudavar, Liman, Boladi, Mahmudavar, Mishkami, Turkoba, Mollaoba, Boradigah, Goytepe, Pirivolnoe, Kazimabad, Taza Alvadi, Uzuntara, Alar, Guvuz and Guvuz. .; Astara, Pensar, Siyavar, Shahagaj, Bala Shahagaj, Shaglakucha, Darguba, Kanzalan, Haftoni, Laj, Masalli, Digah, Old Alvadi, Banbashi, Boyuk Khojavar, Khalilli, Khalilabad, Seyidbazar, to the areas with moderate ecological damage; Lankaran, Jalilabad and nearby settlements are considered to be areas with high ecological damage. Hirkam National Park, forests, high mountainous areas, wetlands and areas used for tourism were marked as almost no damage (Figure 1). 


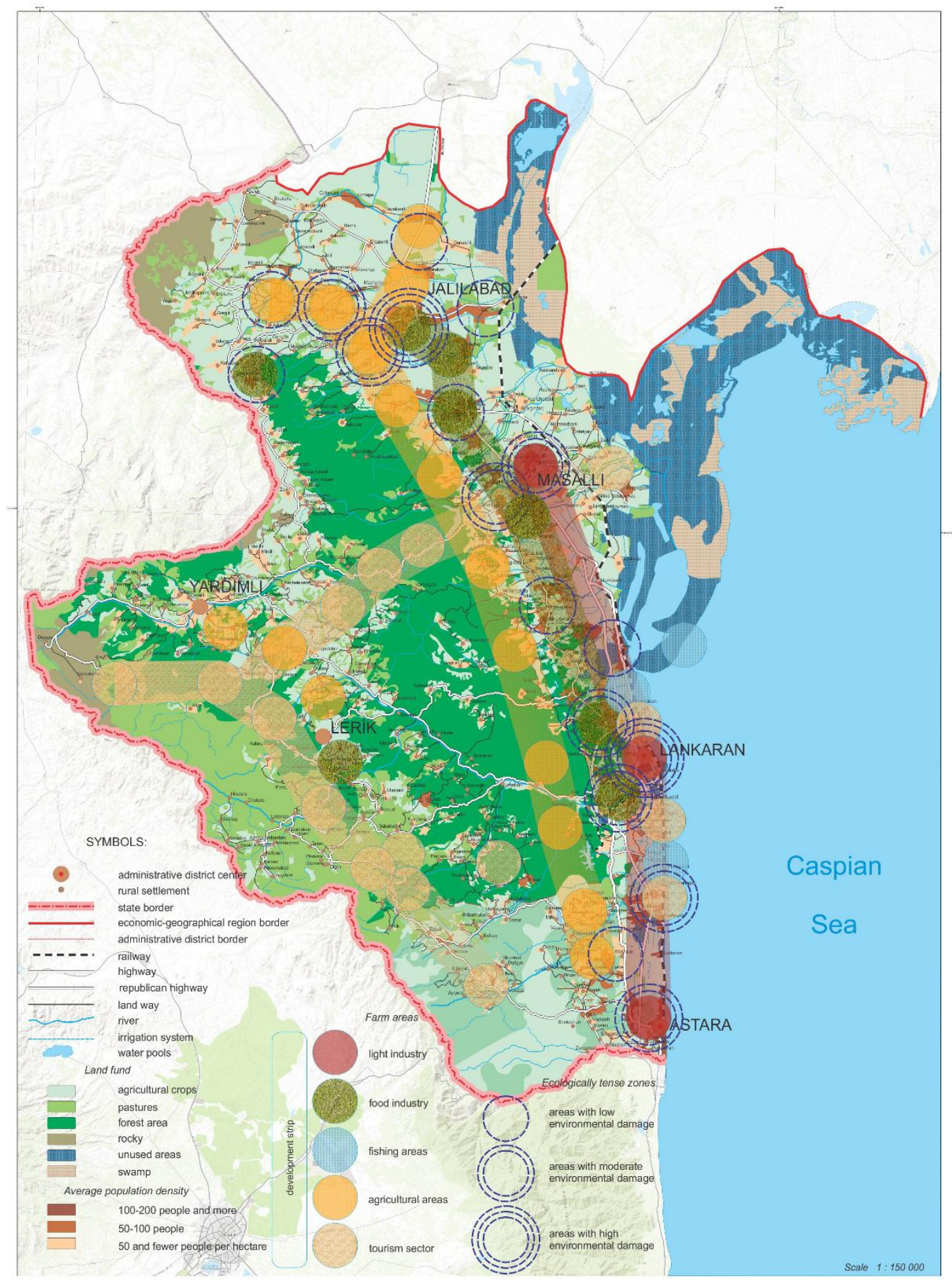

Figure 1. Eco-geographical map of Lankaran physical-geographical region

\section{THE PRACTICAL SIGNIFICANCE OF THE RESEARCH}

The obtained scientific results can be applied in solving eco-geographical problems of the studied area, optimizing human life and economic activities, efficient use of water and land 
resources, ensuring sustainable socio-economic development and development of state programs.

\section{CONCLUSION}

Based on our research, monitoring results, literature, mathematical and statistical analysis and field research, we can say that Lankaran physical-geographical region is more ecogeographically stable than other regions of the country. Both in terms of industry and agriculture, the province is very poorly developed beyond its potential, so the impact on the environment is not so great. The expansion of settlements is mainly along the highways, and these roads almost determine the dynamics of economic development. In the mountainous areas of the region, various types of tourism are being developed, which is an ecologically cleaner and purer economic sector. As this development is related to agriculture in some places, such areas as rural tourism and agro tourism, mountaineering, sports, hiking, ecotourism are being developed in the mountains.

\section{References}

[1] Alexandrov, V.Yu. Kuzubova L.I., Yablokova E.P. (1995). Environmental problems of road transport. Novosibirsk: PO Sever.113 p.

[2] Amarante B.E., Schulz R.K., Romero R.O., Bastida L.E., Güereca, L.P. (2021). Análisis de decisiones multicriterio en la integración de herramientas de la economía ecológica. Revista Universidad y Sociedad, 13(4), 468-477.

[3] Deryabin, V.A. (2016). Ecology Yekaterinburg: Publishing house of the Ural University. $136 \mathrm{p}$.

[4] Golubeva E., Ignatieva M., Korol T., Toporina V. (2012). Eco-geographical approach to the investigation of the stability of cultural landscape. Geography, environment, sustainability, 5(4): p. 63-83. https://doi.org/10.24057/2071-9388-2012-5-4-63-83

[5] Guarino L., Maxted N., Chiwona E.A. (2005). Methodological model for ecogeographic surveys of crops. IPGRI Technical Bulletin No. 9. Rome: International Plant Genetic Resources Institute, $56 \mathrm{p}$.

[6] Khomich, V.A. (2002). Ecology of the urban environment. Omsk: SibADI Publishing House. 267 p. 
[7] Kochinov, Yu.A. Kochinova, T.V. (2014). Transport support for commercial activities. Perm: Publishing house OT and DO, 116 p.

[8] Korendyaseva, E.V. (2017). Environmental aspects of city management. Moscow: MGUU Moscow Government, 140 p.

[9] Regions of Azerbaijan: statistical collection (2019). Baku: DSK. 788 p.

[10] Reserves of the USSR (1990). Reserves of the Caucasus / under total. ed. V.E. Sokolov. Moscow: Mysl, 365 p.

[11] Rodrigue, J.P. (2020). The Geography of Transport Systems. New York: Routledge, 480 p.

[12] Yusifov, E.F. Haciyev V.C. (2004). Hirkan biosphere reserve. Baku: El-ALliance, 168 p. 